\title{
Home or next door? \\ Patenting by European food and beverage multinationals
}

\author{
Catalina Martínez ${ }^{1 *}$ Ruth Rama ${ }^{2}$
}

This is a pre-copy-editing, author-produced PDF of an article accepted for publication in Technology Analysis and Strategic Management following peer review. The definitive publisher-authenticated version [Home of next door? Patenting by European food and beverage multinationals, 2012, Technology Analysis and Strategic Management, 24:7, 647-661] is available online at: DOI: http://dx.doi.org/10.1080/09537325.2012.705118

\begin{abstract}
We study the location of the inventive activity of 59 major European food and beverage multinationals and their 8,432 subsidiaries worldwide, by analysing the geographical distribution of the inventors listed in the EPO applications, USPTO patents and triadic, international and PCT patent families the companies filed between 1978 and the early 2000s. The sampled companies tend to locate their R\&D activities in the home country. EU-based companies, more specifically, deploy an intra-regional strategy in EU countries, especially with regard to the inventions most closely related to their core businesses (food), for which, however, they do not display a home-country preference. Inventions related to non-core business tend to be produced in extra-regional locations.
\end{abstract}

Key words: Technology \& Innovation Studies; Patent analysis; Food industry; Business and corporate strategy; Europe; Multinationals.

JEL classification: F23; O32

1) catalina.martinez@csic.es, Institute of Public Goods and Policies (CSIC-IPP), Madrid, Spain. *Corresp.author.

2) ruth.rama@cchs.csic.es, Department of Economics (CSIC-IEGD), Madrid, Spain. 


\section{1 - Introduction}

Multinational enterprises (MNEs) innovate abroad to adapt their products to host country tastes, absorb new knowledge from world centres of excellence or benefit from low-cost, goodquality local R\&D (Blanc and Sierra 1999; Dunning and Lundan 2009). Despite the internationalisation of R\&D activities having become increasingly common (UNCTAD 2005), most sectoral analyses are still confined to high-tech sectors (Fernández-Ribas and Shapira 2009; Tijssen 2009).

Since MNEs differ in their propensity to engage in R\&D activities abroad, depending on the sector in which they operate (Cantwell and Janne 2000; Patel and Pavitt 1991), studies of mature sectors, such as food and beverages, are also required. Apparently, food and beverage multinationals (hereafter F\&B MNEs) are especially inclined to undertake their R\&D activities abroad (Alfranca et al. 2005; Cantwell and Janne 2000), probably because of the need to adapt their products to different national tastes and food safety regulations. This is of policy interest to home countries and supra national regions. The relocation of indigenous firms' $R \& D$ centres may restrict technological opportunities in the domestic market (Archibugi and Iammarino 1999) and involve a loss of technological capabilities for the home country or, at least, signal that it is insufficiently attractive to innovative MNEs (Sachwald 2005).

According to data from the Confederation of Food and Drink Industries (CIAA), food and drinks is the largest manufacturing industry in the EU, ahead of automobiles or chemicals. It accounted for $13.4 \%$ of manufacturing turnover and was the leading employer in the region. The EU is also a leading exporter of food and drink products. European MNEs are important providers of new technology for the food and drink sector and auxiliary industries (Christensen, Rama and von Tunzelmann 1996). However, the location of the R\&D activities of European F\&B MNEs is insufficiently understood. European F\&B MNEs seem to patent a substantial proportion of their 
innovations outside Europe, notably in the USA (Cantwell and Janne 2000). Actually, the globalisation of corporate R\&D in this sector has been a cause for concern in European countries which depend heavily on agro-industrial production and exports (Bijman et al. 1997). The globalisation of corporate $\mathrm{R} \& \mathrm{D}$ has raised fears that companies could massively relocate their laboratories in foreign countries. This would signal that the National System of Innovation (NSI) has failed to provide the technological support needed by firms (Bijman et al. 1997; Sachwald 2005).

Most studies on this sector have concentrated on patents granted by the US Patent and Trademark Office (USPTO), especially in the 1980s and 1990s. To date, no comparative temporal analysis has been performed of inventions produced inside and outside the EU, and inside and outside EU companies' home countries, by combining different patent data indicators for inventors' locations, as this study does. There is a need to complement previous research work by using contrasting sources of information. Secondly, to our knowledge, there is virtually no research work on the different types of R\&D activities these companies locate at home and abroad (the EU and elsewhere). Specific analyses of corporate R\&D location by technological field are needed.

Improving our understanding of these aspects will help us to discuss whether the attractiveness of European home countries is weak, and which specific technologies $F \& B$ firms eventually need to seek abroad (or in extra-EU locations, in the case of EU-based firms). Investigating these aspects, we attempt to contribute to the formulation of more refined policies towards corporate $\mathrm{R} \& \mathrm{D}$ in the sector.

This paper studies the spatial patterns of R\&D for 59 major European F\&B MNEs and their 8,432 affiliates by examining the locations of the patent inventors. We analyse the 8,626 EPO (European Patent Office) applications filed by these firms in 1978-2005 and the 3,650 USPTO patents they applied for in 1978-2001. We also employ data on patent families of three different types, the earliest priority years of which were between 1978 and 2000: 2,662 triadic, 5,993 
international and 2,462 PCT (Patent Cooperation Treaty) patent families. We consider a relatively long time period to ensure that we capture as many innovations as possible in the conservative food and beverage industry, where consumers’ tastes change slowly (Galizzi and Venturini 2008).

The present article aims to contribute to the empirical literature on the geographic patterns of corporate R\&D in this under-researched sector. Firstly, we find that European F\&B MNEs tend to locate most of their R\&D activities in the home country; focusing on EU-based F\&B MNEs, we also detect such a preference. Secondly, more specifically, EU-based F\&B MNEs tend to locate their R\&D activities within the EU. Thirdly, EU-based F\&B MNEs tend to keep their most strategic inventions (food-related) within the EU though not necessarily in the home country. By contrast, they prefer extra-regional locations for their non-food inventions.

The following section presents a review of the relevant literature and our hypotheses. Section 3 describes the empirical data and methodology employed, while Section 4 describes briefly the main characteristics and innovation patterns of the sampled F\&B MNEs. Section 5 examines the geographical distribution of their inventive activities, and Section 6 tests whether they retain their most strategic R\&D activities at home or abroad, and inside or outside the EU. Section 7 presents a discussion of the results and offers our conclusions.

\section{2 - Background and hypotheses}

Previous research suggests a substantial R\&D internationalisation of major F\&B MNEs. However, most analyses have been based on the number of patents granted by the USPTO and often based only on the location of the first inventor listed in the patent. We attempt to verify whether the apparent importance of $R \& D$ internationalisation in such European firms is confirmed when we employ: i) multiple patent data sources instead of a single source and ii) location indicators for all the inventors listed in patents.

Some authors, defined by Archibugi and Iammarino (1999) as the "sceptics of globalisation", maintained in the 1990s that many MNEs have little interest in internationalising 
their R\&D activities because they prefer to innovate in their home countries (Patel and Pavitt 1991; Patel and Vega 1999). A recent review of the literature on the internationalisation of corporate R\&D suggests that much of the innovative activity of MNEs continues to take place at home (Dunning and Lundan 2009).

Some authors claim that the internationalisation of $\mathrm{R} \& \mathrm{D}$ is in fact largely a regional process, principally involving European MNEs which innovate in other European countries (Archibugi and Michie 1995). Furthermore, European F\&B MNEs display regional strategies with regard to the internationalisation of their manufacturing facilities and show intensive intra-firm trade within the EU (Chevassus-Lozza et al. 2005; Filippaios and Rama 2008). Moreover, according to some studies, corporations do not perform the same type of R\&D at home and abroad. It has been claimed that such companies continue to retain their most important $R \& D$ activities close to their headquarters (Cohen et al. 2009; Narula 2000).

Our hypotheses are thus as follows:

- H1: European F\&B MNEs tend to generate more inventions in their home country than abroad (the hypothesis is also tested, more specifically, for EU-based companies).

- H2: EU-based F\&B MNEs tend to generate more inventions within the EU than elsewhere.

- H3: EU-based F\&B MNEs tend to generate their food-related inventions near their headquarters (preferably in the companies' home countries or at least within the EU).

\section{3 - $\quad$ Empirical data and methodology}

The companies analysed in the present study are European-based MNEs included in the ranking of the world's 100 largest F\&B MNEs in the AGRODATA database, compiled by the Institut Agronomique Méditérrannéen de Montpellier. We combined information from this source and other databases to obtain a global picture of their patenting activities. Firstly, we identified all their affiliates (domestic and foreign) and extracted information regarding their names and locations from the Bureau van Dijk (BvD) AMADEUS database, version March 2008. Secondly, we matched 
such information with the names and locations of applicants in USPTO patent grants and EPO applications and collected data on patent families from the September 2008 EPO Worldwide Patent Statistics Database (PATSTAT).

To date, most studies of patent globalisation have relied on single patent indicators, most often USPTO patent grants (e.g. Patel and Vega 1999; Belderbos 2001; Alfranca et al. 2004). Some exceptions are the multi-sectoral studies by Le Bas and Sierra (2002) and Quintás et al. (2008 and 2009), which employ EPO patent applications. Le Bas and Sierra (2002) highlight their advantages over US patent grant information. The EPO is an international patent office (a one-stop shop to gain protection in the contracting states of the European Patent Convention), rather than a national office granting domestic rights like the USPTO. Furthermore, the two bodies have different disclosure rules. Until 2001 the USPTO only published patent grants, whereas the EPO has always published pre-grant applications. Other authors have signalled that patent applications (i.e. finally granted or not) are more appropriate than granted patents as proxies of the inventive activity of firms, because applications counts are not affected by patent office procedures (Basberg 1987; Dernis and Khan 2004). We agree with the latter and measure invention by both EPO applications and applications filed at different offices to protect the same inventions (patent families), but also perform comparisons with USPTO granted patents, to compare our results with previous studies. Companies prefer to use USPTO to protect the inventions produced in the US. $54 \%$ of the USPTO patents developed abroad by European F\&B MNEs have a US inventor; 94\% if we focus on EU based F\&B MNEs (47\% and 86\% without Unilever, respectively). When academics analyse only this source of information, results tend to overemphasise the R\&D internationalisation of European firms.

From among the variety of patent family definitions (OECD 2009; Martínez 2011), we have chosen, firstly, triadic patent families (priority-related patents filed in the three major patent offices, namely the EPO, USPTO and the Japan Patent Office (JPO)); secondly, international patent 
families (priority-related patents filed in at least two different patent offices); and thirdly, PCT patent families (priority-related patents that involve at least one PCT application). Inclusion within a triadic patent family has been shown to be an indicator of high patent value (Dernis, Guellec and van Pottelsberghe 2001). The other two types of families are more inclusive and aim to capture lower-value patents for which applicants nevertheless seek some sort of international protection.

Patents may list inventors located in different countries. We consider that the invention was produced "abroad" when all the inventors listed in the application are located in countries different from the MNE's home-country, and "at home" when at least one inventor is located in the home country. The definition chosen here is conservative with respect to the definition of inventions produced "abroad", although it should be noted that $82 \%$ of EPO applications and $87 \%$ of US patents in our sample are produced by inventors located in a single country. Likewise, we define inventions produced inside the EU as those having at least one inventor located within the EU, and inventions produced outside the EU as those having no inventor located inside the EU. For the latter we take into account changes in the composition of the EU over the years, by taking EU-15 for the period 1978-1994 and EU-27 for 1995 onwards. We consider inventions produced in the countries which accessed the EU in the 1980s and 1990s throughout the first period (and not merely from their accession) to be EU-15 inventions, as F\&B MNEs entered these markets or expanded their existing business well in advance of the EU enlargement (Anastassopoulos et al. 1997). We follow the same approach for the ten new member countries that joined the EU in the mid-2000 (Chobanova 2009).

Finally, we define food-related inventions as those having at least one IPC (International Patent Classification) class within the technology subfields "Food and Agriculture" or "Food and Agriculture Machines \& Tools" of the 30 technology subclasses established in the 2nd revision of the IPC correspondence OST-INPI/FhG-ISI. In turn, non-food-related inventions (hereafter, nonfood inventions) are those without an IPC class in these two subfields. 
We proceed in three steps. Firstly, we test H1 with an analysis at the firm level. We apply a Wilcoxon signed-rank test for paired samples to compare, by company and year, the number of their patents invented at home and the number of their patents invented abroad. For instance, we compare the patents produced by Nestlé at home and abroad in 1978, in 1979, etc.. We use a non parametric test because the distribution of the variables was not normal. The hypothesis is tested with the whole sample and with a subsample of EU-based companies; in both cases Unilever is excluded owing to its bi-nationality (UK and The Netherlands). Secondly, focusing on EU-based companies, we test $\mathrm{H} 2$ also with data at the company level. We apply a Wilcoxon signed-rank test to compare, by company and year, the number of their patents generated within the EU (homecountry included) and the number of their patents generated elsewhere. In this case Unilever is included in the sample since its two headquarters are located within the EU. Finally, we test H3 with an analysis at the patent level. We apply a Chi Square to test the association of the type of invention (food-related or not) and localisation of inventors. For the latter, two different comparisons are undertaken: home v abroad and EU v elsewhere. We use a Chi-square test because we study the association of categorical variables.

\section{4 - European F\&B MNEs and innovation}

Table 2 displays some characteristics of the sample. The parent companies are based in 11 EU countries and Switzerland. These companies are highly internationalised since they located 54\% of their affiliates in foreign countries in 2008. EU-based companies, excluding Unilever, mainly located their foreign subsidiaries in the EU (67\%) and the US (7\%). The largest companies, as measured by total sales, food sales or employment are Nestlé and Unilever.

$14 \%$ of the sampled F\&B MNEs did not file any EPO applications in the period considered, while $37 \%$ filed over 25 applications. A similar situation is reflected by USPTO patent grants. This 
evidence confirms a previous study based on US patent granted to the world's largest F\&B MNEs (Alfranca, Rama and von Tunzelmann 2004), which concluded that a small nucleus of innovators directed innovation in this international industry and, moreover, that a considerable number of $\mathrm{F} \& \mathrm{~B}$ MNEs only patented sporadically or not at all. Whichever patent proxy is employed, Unilever and Nestlé are the European technological leaders.

$$
* * * \text { Table } 2 * * *
$$

Both the total number of EPO patent applications and granted USPTO patents filed by the largest European F\&B MNEs rose significantly during the period (from 15 applications in 1978 to 494 in 2005 and from 53 patents in 1978 to 351 in 2001).

Non-food applications accounted for $64 \%$ of total EPO applications and $75 \%$ of USPTO grants. These results are coherent with previous studies which note the substantial share of nonfood innovation produced by the world's largest F\&B MNEs (Alfranca et al. 2003; von Tunzelmann 1998). F\&B MNEs innovate in non-food fields for two main reasons: firstly, some of them are conglomerates which also produce non-food items (e.g. Unilever); secondly, and more importantly, F\&B MNEs need to acquire expertise in the upstream technology used for food production. Since approaches to food quality and safety are becoming increasingly multidisciplinary (Christensen, Rama and von Tunzelmann 1996), non-food-based innovation may well help F\&B companies to interact better with their suppliers of technology. Consequently, even companies dedicated exclusively to food production devote part of their innovative efforts to non-food innovation (Alfranca, Rama and von Tunzelmann 2003).

\section{5 - Home or next door?}

We test whether the sampled European MNEs prefer to invent in their home country (H1); and secondly, more specifically, if EU MNEs show a preference for the EU (H2). 
The share of patents or applications generated abroad (excluding Unilever due to its binationality) accounted to $56 \%$ of their USPTO patents in $1978-2001,42 \%$ of their EPO applications in 1978-2005, and, respectively, 33\%, 34\% and 37\% of their triadic, international and PCT families in 1978-2000. Wilcoxon signed-rank tests confirm that EPO applications tend to be generated in home countries $(\mathrm{Z}=-8.131$; $\mathrm{p}$-value $=0.000, \mathrm{~N}=540)$. As stated, here cases are observations for each company in each year. The negative sign of $\mathrm{Z}$ indicates that most of the ranks were negative (inventions performed abroad < inventions performed at home); results are statistically significant. Though the influence of foreign inventions appears to be higher, results are similar for US patents $(Z=-1.823 ; p$-value $=0.068 ; N=331)$. Finally, patent families are also predominantly generated at home (triadic families $\mathrm{Z}=-6.171$, p-value $=0.000 ; \mathrm{N}=222$; international families $Z=-8.813$, $p$-value $=0.000, N=418$; PCT families $Z=-4.221$, $p$-value $=$ $0.000, \mathrm{~N}=242)$.

When we focus more specifically on EU-based F\&B MNEs (also excluding Unilever), all five patent indicators show a preference for the home country, with only $38 \%$ of US patents produced abroad (32\% of EPO applications, $34 \%$ of triadic, $32 \%$ of international and $36 \%$ of PCT families). The Wilcoxon signed-rank tests are all statistically significant and $\mathrm{Z}$ displays negative signs. Differences between the European sample and the EU subsample reflect the influence of Nestle in the results, as it produces $52 \%$ of its US patents outside Switzerland. The statistical tests show that EU-based companies produce most of their inventions in the home-country.

Our results suggest that studies which focus solely on USPTO data may exaggerate the importance of the internationalisation of $\mathrm{R} \& \mathrm{D}$ in the European $\mathrm{F} \& \mathrm{~B}$ sector, not only simply because they rely on a single indicator, but also because by doing so they are not taking into account the influence of the composition of the sample when some firms, especially the largest patentees, may behave differently depending on the indicator used (Table 3). 
We test now whether the 56 EU-based F\&B MNEs in our sample tend to produce their inventions in the EU (home country included) or in extra-EU locations; this time Unilever is not eliminated from the sample as both its parent companies are based in the EU.

We observe a preference for EU countries, although again, the choice of intra-regional locations is accentuated in EPO applications and patent families. EU based F\&B MNEs produce only $18 \%$ of EPO applications and triadic families, $13 \%$ of international families, $11 \%$ of PCT families outside the EU, compared to $38 \%$ of US patents. The Wilcoxon signed-rank tests display statistically significant results and confirms the companies' preference for intra-EU locations with regard to all types of patents. $\mathrm{Z}$ always displays negative signs, indicating that the number of patents or applications generated outside the EU is below the number of patents or applications generated within the EU $($ EPO Z $=-18.364$, p-value $=0.000, \mathrm{~N}=531$; USPTO Z $=-9.449$, p-value $=0.000$, $\mathrm{N}=324$; Triadic families $\mathrm{Z}=-11.044, \mathrm{p}$-value $=0.000, \mathrm{~N}=219$; international families $\mathrm{Z}=-$ 16.465, p-value $=0.000, \mathrm{~N}=414 ;$ PCT families $\mathrm{Z}=-12.462, \mathrm{p}$-value $=0.000, \mathrm{~N}=243)$. Interestingly, when Unilever is excluded, we find that only $20 \%$ of US patents are produced outside the EU, instead of $38 \%$.

According to our data, more than $85 \%$ of EU-based F\&B MNEs have a regional innovation strategy as they generate at least $50 \%$ of their patents within the EU. Even the most important patentees follow such a strategy (for a description of regional strategies in this industry see Fillippaios and Rama 2008). With the exception of Unilever, the top EU-based patentees have all located more than $60 \%$ of their inventions within the EU (Table 4).

\footnotetext{
*** Table $4 * * *$
} 


\section{6 - The location of strategic innovation}

As stated, non-food inventions account for most of the patentable inventions of the sampled companies. Their share of total EPO applications tended to fall from $67 \%$ to $63 \%$ from 1978-1990 to $1991-2005$. In contrast, their share of US patents increased, from $64 \%$ in $1978-1990$ to $79 \%$ in 1990-2001. The most dynamic field is pharma-biotechnology (from 29\% of non-food patents granted to the sampled companies in $1978-1990$ to $63 \%$ in $1991-2001$, and from $31 \%$ of their EPO non-food applications in 1978-1990 to $36 \%$ in 1990-2005).

We test if EU based F\&B MNES locate their most strategic innovative activities, i.e. foodrelated inventions, in the home country (or, at least, within the EU); again, we employ the location of the inventor to proxy the location of the invention.

The nature of inventions (food and non-food) is apparently unrelated to whether inventors are located in the MNE's home country or abroad (Table 5). $\chi^{2}$ tests show inconclusive results owing to discrepancies between the data sources and weak Cramer's V.

We obtain quite different results when we compare intra and extra EU locations. Employing USPTO, EPO or patent family data, we find in most cases significant statistical associations between the type of invention and inventor location (Table 6). The association of the variables is statistically significant and Cramer's V indicates moderate relationships between them. The strength of the association tends to be reinforced from the first period to the second. Increasingly, the companies tend to produce their most strategic inventions (food-related) within the EU. According to USPTO data, $29 \%$ of the inventions produced within the EU-15 in the first period and $37 \%$ of the inventions produced within the EU-27 in the second are food-related (compared to only $9 \%$ and $13 \%$, respectively, of those produced in extra-regional locations). In turn, EPO data show that $30 \%$ of the inventions produced within the EU-15 in the first period and $37 \%$ of the inventions achieved within the EU-27 in the second period are food-related (compared to only $11 \%$ and $15 \%$, respectively, of those produced in extra-regional locations). 
To summarise, EU F\&B MNEs tend to retain their food-related R\&D activities within the EU, although they show no particular preference for home countries. Non-food inventions are principally produced in extra-regional locations.

$$
* * * \text { Tables } 5 \text { and } 6 * * *
$$

\section{7 - Discussion and conclusions}

We have investigated where do the largest European food and beverage MNEs tend to produce their patentable innovations employing a variety of R\&D indicators (EPO applications, US patents and three different types of patent families). Our results show, firstly, that analyses which rely solely on USPTO data may have exaggerated the importance of R\&D internationalisation. As MNEs in other highly internationalised industries (Dunning and Lundan 2009; Patel and Pavitt 1991; Patel and Vega 1999), the sampled MNEs preferred to produce most of their patentable inventions at home during the analysed period. These studies analyse companies which have internationalised their sales or assets but still prefer locating their R\&D activities in their homecountries. Our results may also seem counterintuitive since the sampled firms display extensive internationalisation of their affiliates. A possible explanation is that F\&B MNEs could have built useful R\&D linkages with universities and suppliers in the home-country; similar culture and common language are important vehicles for the communication of knowledge (Mansfield 1991). Furthermore, while adapting products to local tastes and regulations is certainly crucial for these firms, many of the innovative activities performed abroad may actually account for minor, non patentable improvements. Secondly, EU based companies tend to locate their R\&D activities mainly within the EU, especially those related to their core business (food). Our results do not support the thesis that companies retain their most strategic research in their home countries (Criscuolo et al. 2002), although they prefer to develop it within the EU.

Even the most important EU patentees in our sample follow a regional strategy. Several reasons may help to explain this result. Similar norms (e.g. environmental norms for packaging) 
may have played some role. Moreover, this regional R\&D strategy is in accordance with the regional strategies adopted by EU F\&B MNEs concerning production and intra-firm trade (Filippaios and Rama 2008; Chevassus-Loza et al. 2005). Results of economic integration are noticeable in the distribution of foreign affiliates of the sampled EU companies, which clearly display a preference for EU host-countries. To summarise, the industry leaders seem to perform mainly on an intra-regional basis, rather than globally. In spite of the debate on globalization strategies, managers of $\mathrm{F} \& \mathrm{~B}$ companies may find it useful to pay special attention to regional strategies concerning $\mathrm{R} \& \mathrm{D}$ location. Our findings also suggest that these companies may be drawing strategic knowledge related to food production from the EU rather than solely the home country. Companies prefer to locate their technical expertise in food sciences within the EU, an option which suggests that regional sectoral systems of innovation provide their laboratories with sufficient support. It has been claimed (although not yet proven) that the new knowledge which European agro-food firms require is currently underdeveloped in Europe, as National Systems of Innovation (hereafter NSI) are unable to supply such companies with adequate information and support. NSIs may be evolving more slowly than corporate technological requirements (Narula 2000). Our results do not support this idea, at least with regard to food related inventions. Moreover, our data support the opinion (Van Rooij et al. 2010) that analyses should look beyond the NSI; in the case of EU based F\&B companies, there is a need to pay attention to supra-national sources of knowledge. Since the companies concentrate most of their food-related inventions within the EU, improved intra-EU coordination of food research and of education in agriculture and food science may be useful. Such measures could help to increase the internal R\&D capabilities of not only the large MNEs sampled here but also those of smaller European F\&B companies still on the path towards internationalisation

We also find that EU-based F\&B MNEs tend to produce their non-food innovations in extraregional locations. Non-food innovation may account for companies' incursions into technologies 
relatively new to them, probably best characterised as Home Based Augmenting (HBA) technological activities (Kuemmerle 1999). Our results suggest that, at least for MNEs based in the EU, the HBA logic might apply to the regional rather than the national level; confirming the need to look beyond the NSI. Given the substantial industrial diversification of F\&B MNEs (Anastassopoulos and Rama 2005), their non-food technology requirements may involve a variety of technical fields. As it is impossible for any nation or supra-national region to excel in all technological fields, our results do not necessarily indicate a weakening of European systems of innovation. Our results suggest that when the F\&B company is a substantial producer of non-food inventions, two different location strategies may be needed, one regional for food related inventions and one global for non-food. Thus, in accordance with Cantwell (1995), F\&B MNEs would tap into foreign centres of expertise and choose multiple locations for their technological activity, food and non-food, instead of, as predicted by the early product life cycle model, simply exploiting their own technological strengths.

However, from a policy perspective our results concerning non-food inventions suggest various reasons for concern. Firstly, non-food R\&D activities account for the largest and most dynamic share of such companies' innovative activities. Secondly, as some authors have suggested (Alfranca et al. 2003), European F\&B MNEs may be involved, in part, in non-food R\&D because they need to research important inputs required to produce food (and not necessarily because of their industrial diversification). Food production nowadays involves a broad spectrum of sciences and techniques, ranging from biotechnology to specialised software and instruments (Christensen et al 1996). In contrast, the preference of EU F\&B MNEs for foreign locations with regard to nonfood technology may point to European weaknesses in some important technical fields. A strengthening, within the EU, of non-food research specifically required for food production may be desirable, in order to attract indigenous F\&B MNEs and their laboratories and to increase the competitiveness of European food and drink companies. 


\section{Acknowledgements}

We thank Stéphane Maraut for the matching of patents with company groups, Juan Fernández-Sastre for research assistance, and Selma Tozanli and José Manuel Rojo for their help with the data. We also thank two anonymous referees for useful suggestions. Ruth Rama acknowledges support provided by the PRIME project, European Union, and Catalina Martínez thanks support from CSIC (200610I142). 


\section{References}

Abramovsky, L., R. Griffith, G. Macartney and H. Miller. 2008. The location of innovative activity in Europe. The Institute for Fiscal Studies. WP 08/10.

Alfranca, O, R. Rama, and N. von Tunzelmann. (2003). "Technological fields and concentration of innovation among food and beverage multinationals." International Food and Agribusiness Management Review 5, 3-16.

. (2004). Innovation spells in the multinational agrifood sector. Technovation, 24, 599-614.

- (2005). "Innovation in food and beverage multinationals." Pp. 13-50 in Multinational agribusinesses, edited by R. Rama. New York and London: Haworth Press Inc.

Anastassopoulos, G., M. Papanastassiou, R.D. Pearce, and W.B. Traill. (1997). "Firm and location. Specific determinants in investment and trade strategies of major multinationals in the food industry in Europe." Pp. 57-78 in Foreign direct investment and processed food trade, edited by S.R.Henneberry. Oklahoma State University, Oklahoma (US).

Anastassopoulos, G., and R. Rama. (2005). "The Performance of Multinational Agribusinesses: Effects of Product and Geographical Diversification." Pp. 73-113 in Multinational agribusinesses, edited by R. Rama. New York and London: Haworth Press Inc.

Archibugi, A., and S. Iammarino. (1999). "The policy implications of the globalisation of innovation." Research Policy 28:317-336.

Basberg, B. 1987. Patents and the measurement of technological change: a survey of the literature. Research Policy (16), 131-141.

Bijman, W.B., R. van Tulder, and M. van Vliet. 1997. "Agribusiness, R\&D and internationalization. Internationalization strategies of agribusiness firms and their implications for the firm's knowledgemanagement." The Hague: NRLO.

Blanc, H., and C. Sierra. (1999). "The internationalisation of R\&D by multinationals: a trade-off between external and internal proximity." Cambridge Journal of Economics 23:187-206.

Cantwell, J. (1995). "The globalisation of technology: what remains of the product cycle model?" Cambridge Journal of Economics 19: 155-174.

Cantwell, J., and O. Janne. (2000). "Globalization of innovatory capacity: the structure of competence accumulation in European home and host countries." Pp. 121-177 in European integration and global corporate strategies, edited by F. Chesnais, G. Ietto-Gillies, and R. Simonetti. London-NY: Routledge.

Cohen, S.S., A. Di Minin, Y. Motoyama, and C. Palmberg. (2009). "The persistence of home bias for important R\&D in wireless telecom and automobiles." Review of Policy Research 26:55-77.

Chevassus-Lozza, E., J. Gallezot, and D. Galliano. (2005). "External versus internal markets of the multinational enterprises: intrafirm trade in French multinational agribusiness." Pp. 191-218 in Multinational Agribusinesses, edited by R. Rama. N.Y. and London: Haworth Press Inc.

Christensen, J. L., Rama, R., \& von Tunzelmann, N. (1996). Study on Innovation in the European Food Products and Beverages Industry (No. EIMS SPRINT). EIMS/SPRINT Brussels: The European Commission.

Chobanova, Y. (2009). Strategies of multinationals in Central and Eastern Europe Innovation Systems and Embeddedness: Palgrave.

Criscuolo, P., R. Narula and B. Verspagen 2002. The relative importance of home and host innovation systems in the internationalisation of MNE R\&D: a patent citation analysis. Eindhoven Center for Innovation Studies. Working Paper 02.20.

Dernis, H., D. Guellec and B. van Pottelsberghe de la Potterie. 2001. Using patent counts for cross-country comparisons of technology output. OECD STI Review, 27. OECD. Paris.

Dunning, J.H., and S.M. Lundan. (2009). "The internationalization of corporate R\&D: A review of the evidence and some policy implications for home countries." Review of Policy Research 26:13-34.

Fernández-Ribas, A., and P. Shapira. (2009). "Technological diversity, scientific excellence and the location of inventive activities abroad: the case of nanotechnology." Journal of Technology Transfer 34:286303. 
Filippaios, F, and R.. Rama. (2008). "Globalisation or regionalistion? The strategies of the world's largest food and beverages MNEs." European Management Journal 26:59-72.

Galizzi, G., and L. Venturini. (2008). "Nature and determinants of product innovation in a competitive environment of changing vertical relationships." Pp. 51-80 in Handbook of innovation in the food and drink industry, edited by Ruth Rama. New York and London: Taylor \& Francis Group.

Kuemmerle, W. (1999). "Foreign direct investment in industrial research in the pharmaceutical and electronic industries-results from a survey of multinational firms". Research Policy 28: 179-93.

Le Bas, C., and C. Sierra. (2002). "'Location versus home country advantages' in R\&D activities: some further results on multinationals' locational strategies." Research Policy 31:589-609.

Mansfield, E. (1991). "Academic research and industrial innovation." Research Policy 20:1-12.

Marsland, R. 2003. Unilever's IP Management: creating the bedrock for global brands. Intellectual Asset Management. July/August 2003. 14-18.

Martínez, C. 2011. Patent families: when do different definitions really matter? Scientometrics (86), 39-63.

Narula, R. 2000. "Explaining "inertia" in R\&D internationalisation: Norwegian firms and the role of home country-effects." Pp. 1-39 in Research Memoranda, edited by Maastricht Economic Research Institute on Innovation and Technology. Maastricht.

OECD. 2009. Patent Statistics Manual. OECD, Paris.

Patel, P. , and K. Pavitt. (1991). "Large firms in the production of the world's technology: an important case of 'non-globalisation." Journal of International Business Studies 22:1-21.

Patel, P. , and M. Vega. (1999). "Patterns of internationalisation of corporate technology: location vs. home country advantages." Research Policy 28:145-155.

Quintás, M., X. H. Vázquez, J.M. García and G. Caballero. 2008. Geographical amplitude in the international generation of technology: present situation and business determinants. Research Policy (37), 1371-1381.

Quintás, M., X. H. Vázquez, J.M. García and G. Caballero. 2009. International generation of technology: an assessment of its intensity, motives and facilitators' Technology Analysis \& Strategic Management (21), 6, 743-763.

Rugman, A., and A. Verbeke. (2004). "A perspective on regional and global strategies of multinational enteprises." Journal of International Business Studies 35:3-18.

Sachwald, F. (2005). "Mondialisation et attractivité de la France pour la R\&D des entreprises." in Le système français d'innovation dans l'économie mondiale: enjeux et priorités, edited by $\mathrm{P}$. Larédo and $\mathrm{F}$. Sachwald. Paris: IFRI-Institut de l'Entreprise.

Tijssen, R.J.W. (2009). "Internationalisation of pharmaceutical R\&D: how globalised are Europe's largest multinational companies?" Technology Analysis \& Strategic Management 21:859-879.

UNCTAD. 2005. "World Investment Report 2005. Transnational corporations and the internationalization of R\&D." Pp. 331. New York and Geneva: United Nations.

Van Rooij, A., E. Berkers, M. Davids, and F. Veraart. (2010). "National innovation systems and international knowledge flows: an exploratory investigation with the case of the Netherlands." Technology Analysis and Strategic Management 20:149-168.

von Tunzelmann, G.N. (1998). "Localized technological search and multi-technology companies." Economics of Innovation and New Technology 6:231-255. 


\section{TABLES AND FIGURES MAIN TEXT}

Table 1. Variables description

Variable

Definition

Values

Type of invention

\begin{tabular}{l|l|c|c|c|} 
Food-related & Technology subfields "Food and Agriculture" or "Food and Agriculture Machines \& Tools" & Yes/No
\end{tabular} Inventor location

\begin{tabular}{c|c|c} 
Home & At least one inventor located in home-country of company & Yes/No \\
\hline EU-15 & At least one inventor located in EU-15 & Yes/No \\
\hline EU-27 & At least one inventor located in EU-27 & Yes/No \\
\hline
\end{tabular}

Notes : (1) $1^{\text {st }}$ period: 1978-1994; (2) $2^{\text {nd }}$ period: 1995-2005 for EPO applications, 1995-2001 for USPTO patents and

1995-2000 for the families.

Table 2. Description of the sample

\begin{tabular}{|c|c|c|c|c|c|c|c|}
\hline $\begin{array}{l}\text { COMPANY SIZE } \\
\text { (Parent company information for fiscal year 2005) }\end{array}$ & $\mathbf{N}$ & Min. & \multicolumn{2}{|c|}{ Max. } & Mean & Std dev. & Sum \\
\hline Sales (in millions of euros) & 59 & 647 & \multicolumn{2}{|c|}{58,452} & $5,546.39$ & $9,058.86$ & $327,236.76$ \\
\hline Food sales (in millions of euros) & 57 & 300 & \multicolumn{2}{|c|}{54,626} & $4,853.37$ & $7,809.42$ & $276,642.13$ \\
\hline Employment (number of employees) & 59 & 1,487 & & & 23,793 & 43,131 & 1,403785 \\
\hline HOME COUNTRIES & \multicolumn{3}{|c|}{$\begin{array}{l}\text { \% of parent companies } \\
(\mathrm{N}=59)\end{array}$} & \multicolumn{3}{|c|}{$\begin{array}{l}\text { TOP LOCATIONS OF } \\
\text { AFFILIATES }\end{array}$} & $\begin{array}{l}\text { \% of total, domestic and foreign } \\
\qquad(\mathrm{N}=8432)\end{array}$ \\
\hline United Kingdom & \multicolumn{3}{|c|}{22.0} & \multicolumn{3}{|c|}{ United Kingdom } & 27.5 \\
\hline France & \multicolumn{3}{|c|}{18.6} & \multicolumn{3}{|c|}{ France } & 8.4 \\
\hline Netherlands & \multirow{2}{*}{\multicolumn{3}{|c|}{$\frac{13.6}{85}$}} & \multicolumn{3}{|c|}{ Germany } & 7.3 \\
\hline Germany & & & & Neth & & & 6.3 \\
\hline Ireland & & & & Irela & & & 6.1 \\
\hline Italy & & & & Unit & & & 4.9 \\
\hline Denmark & & & & Spai & & & 3.0 \\
\hline Switzerland & & & & Italy & & & 2.6 \\
\hline Spain & & & & Dent & & & 1.9 \\
\hline Belgium & & & & Chin & & & 1.9 \\
\hline Finland & & & & Pola & & & 1.7 \\
\hline Sweden & & & & Belg & & & 1.6 \\
\hline PATENT COUNTS & & $\mathbf{N}$ & Min. & Max. & Mean & Std dev. & Sum \\
\hline EPO patent applications (filing years 1978-2005) & & 51 & 1 & 4,833 & 169.14 & 722.25 & 8,626 \\
\hline Food-related & & 51 & 0 & 1,160 & 61.33 & 217.30 & 3,128 \\
\hline Home & & 51 & 0 & 1,376 & 69.80 & 230.85 & 3,560 \\
\hline Inside EU15 (1978-1994)) & & 39 & 0 & 1,903 & 66.61 & 303.18 & 2,598 \\
\hline Inside EU27 (1995-2005) & & 48 & 0 & 1,883 & 73.02 & 277.23 & 3,505 \\
\hline USPTO patent grants (filing years 1978-2001) & & 44 & 1 & 2,244 & 82.95 & 347.37 & 3,650 \\
\hline Food-related & & 44 & 0 & 433 & 20.34 & 68.82 & 895 \\
\hline Home & & 44 & 0 & 476 & 24.75 & 74.69 & 1,089 \\
\hline Inside EU15 (1978-1994)) & & 40 & 0 & 566 & 23.92 & 89.87 & 957 \\
\hline Inside EU27 (1995-2001) & & 37 & 0 & 701 & 32.32 & 118.57 & 1,196 \\
\hline Triadic families (earliest priorities 1978-2000) & & 36 & 1 & 1,370 & 73.94 & 267.82 & 2,662 \\
\hline $\begin{array}{l}\text { Food-related } \\
\end{array}$ & & 36 & 0 & 576 & 28.52 & 104.51 & 1,027 \\
\hline Home & & 36 & 0 & 613 & 38.75 & 131.50 & 1,395 \\
\hline Inside EU15 (1978-1994)) & & 29 & 0 & 784 & 39.44 & 146.07 & 1,144 \\
\hline $\begin{array}{l}\text { Inside EU27 (1995-2000) } \\
\end{array}$ & & 31 & 0 & 313 & 20.80 & 64.14 & 645 \\
\hline International families (earliest priorities 1978-2000) & & 46 & 1 & 3,416 & 130.28 & 537.43 & 5,993 \\
\hline $\begin{array}{l}\text { Food-related } \\
\end{array}$ & & 46 & 0 & 951 & 49.56 & 157.87 & 2,280 \\
\hline Home & & 46 & 0 & 1,406 & 67.52 & 242.36 & 3,106 \\
\hline Inside EU15 (1978-1994)) & & 39 & 0 & 1,889 & 69.23 & 301.49 & 2,700 \\
\hline Inside EU27 (1995-2000) & & 44 & 0 & 1,008 & 42.77 & 159.65 & 1,882 \\
\hline PCT families (earliest priorities 1978-2000) & & 36 & 1 & 1,469 & 68.39 & 251.89 & 2,462 \\
\hline Food-related & & 36 & 0 & 288 & 23.02 & 63.66 & 829 \\
\hline Home & & 36 & 0 & 854 & 41.11 & 147.42 & 1,480 \\
\hline Inside EU15 (1978-1994)) & & 28 & 0 & 447 & 23.32 & 83.34 & 653 \\
\hline Inside EU27 (1995-2000) & & 35 & 0 & 837 & 38.05 & 142.56 & 1,332 \\
\hline
\end{tabular}

Sources: Own elaboration based on AGRODATA, BvD AMADEUS, PATSTAT. 
Table 3. Inventors located in the home country: Top 10 European F\&B MNEs ${ }^{(1)}$

\begin{tabular}{|c|c|c|c|c|c|c|c|c|c|c|c|}
\hline \multirow[b]{2}{*}{ Company Name } & \multirow[b]{2}{*}{ Home country } & \multicolumn{2}{|c|}{$\begin{array}{c}\text { \% EPO applications } \\
\text { Filing 1978-2005 } \\
\end{array}$} & \multicolumn{2}{|c|}{$\begin{array}{c}\text { \% US patent grants } \\
\text { Filing 1978-2001 } \\
\end{array}$} & \multicolumn{2}{|c|}{$\begin{array}{l}\% \text { Triadic families } \\
\text { Priority 1978-2000 } \\
\end{array}$} & \multicolumn{2}{|c|}{$\begin{array}{l}\text { \% International families } \\
\text { Priority 1978-2000 } \\
\end{array}$} & \multicolumn{2}{|c|}{$\begin{array}{c}\% \text { PCT families } \\
\text { Priority 1978-2000 }\end{array}$} \\
\hline & & Home & Abroad & Home & Abroad & Home & Abroad & Home & Abroad & Home & Abroad \\
\hline Unilever (2) & Netherlands & $28 \%$ & $72 \%$ & $21 \%$ & $79 \%$ & $39 \%$ & $61 \%$ & $41 \%$ & $59 \%$ & $58 \%$ & $42 \%$ \\
\hline Nestlé & Switzerland & $48 \%$ & $52 \%$ & $17 \%$ & $83 \%$ & $68 \%$ & $32 \%$ & $64 \%$ & $36 \%$ & $63 \%$ & $37 \%$ \\
\hline Danisco & Denmark & $59 \%$ & $41 \%$ & $51 \%$ & $49 \%$ & $51 \%$ & $49 \%$ & $60 \%$ & $40 \%$ & $67 \%$ & $33 \%$ \\
\hline Danone & France & $78 \%$ & $22 \%$ & $71 \%$ & $29 \%$ & $75 \%$ & $25 \%$ & $74 \%$ & $26 \%$ & $80 \%$ & $20 \%$ \\
\hline Heineken & Netherlands & $75 \%$ & $25 \%$ & $82 \%$ & $18 \%$ & $83 \%$ & $17 \%$ & $74 \%$ & $26 \%$ & $71 \%$ & $29 \%$ \\
\hline Ferrero & Italy & $73 \%$ & $27 \%$ & $41 \%$ & $59 \%$ & $87 \%$ & $13 \%$ & $77 \%$ & $23 \%$ & $71 \%$ & $29 \%$ \\
\hline Pernod Ricard & France & $42 \%$ & $58 \%$ & $33 \%$ & $67 \%$ & $33 \%$ & $67 \%$ & $40 \%$ & $60 \%$ & $38 \%$ & $62 \%$ \\
\hline Campina & Netherlands & $92 \%$ & $8 \%$ & $95 \%$ & $5 \%$ & $92 \%$ & $8 \%$ & $95 \%$ & $5 \%$ & $89 \%$ & $11 \%$ \\
\hline Numico & Netherlands & $69 \%$ & $31 \%$ & $69 \%$ & $31 \%$ & $50 \%$ & $50 \%$ & $52 \%$ & $48 \%$ & $50 \%$ & $50 \%$ \\
\hline Barilla & Italy & $97 \%$ & $3 \%$ & $100 \%$ & $0 \%$ & $100 \%$ & $0 \%$ & $97 \%$ & $3 \%$ & $67 \%$ & $33 \%$ \\
\hline
\end{tabular}

Notes: (1) Ranking based on EPO applications filed in 1978-2005. (2) Considered to be a Dutch company, following

AGRODATA and because its food research centre is in the Netherlands (Marsland 2003).

Source: Own elaboration based on AGRODATA, BvD AMADEUS, PATSTAT.

Table 4. Inventors located in the EU: Top 10 EU-based F\&B MNEs ${ }^{(1)}$

\begin{tabular}{|c|c|c|c|c|c|c|c|c|c|c|c|}
\hline \multirow[b]{2}{*}{ Company Name } & \multirow[b]{2}{*}{ Home country } & \multicolumn{2}{|c|}{$\begin{array}{l}\text { \% EPO applications } \\
\text { Filing 1978-2005 }\end{array}$} & \multicolumn{2}{|c|}{$\begin{array}{l}\text { \% US patent grants } \\
\text { Filing 1978-2001 }\end{array}$} & \multicolumn{2}{|c|}{$\begin{array}{l}\% \text { Triadic families } \\
\text { Priority 1978-2000 }\end{array}$} & \multicolumn{2}{|c|}{$\begin{array}{l}\% \text { International families } \\
\text { Priority 1978-2000 }\end{array}$} & \multicolumn{2}{|c|}{$\begin{array}{c}\% \text { PCT families } \\
\text { Priority 1978-2000 }\end{array}$} \\
\hline & & $\mathrm{EU}^{(3)}$ & Elsewhere & $\mathrm{EU}^{(3)}$ & Elsewhere & $\mathrm{EU}^{(3)}$ & Elsewhere & $\mathrm{EU}^{(3)}$ & Elsewhere & $\mathrm{EU}^{(3)}$ & Elsewhere \\
\hline Unilever (2) & Netherlands & $78 \%$ & $22 \%$ & $56 \%$ & $44 \%$ & $80 \%$ & $20 \%$ & $85 \%$ & $15 \%$ & $87 \%$ & $13 \%$ \\
\hline Danisco & Denmark & $86 \%$ & $14 \%$ & $61 \%$ & $39 \%$ & $81 \%$ & $19 \%$ & $88 \%$ & $13 \%$ & $95 \%$ & $5 \%$ \\
\hline Danone & France & $96 \%$ & $4 \%$ & $96 \%$ & $4 \%$ & $96 \%$ & $4 \%$ & $97 \%$ & $3 \%$ & $96 \%$ & $4 \%$ \\
\hline Heineken & Netherlands & $95 \%$ & $5 \%$ & $96 \%$ & $4 \%$ & $94 \%$ & $6 \%$ & $96 \%$ & $4 \%$ & $96 \%$ & $4 \%$ \\
\hline Ferrero & Italy & $98 \%$ & $2 \%$ & $100 \%$ & $0 \%$ & $96 \%$ & $4 \%$ & $98 \%$ & $2 \%$ & $94 \%$ & $6 \%$ \\
\hline Pernod Ricard & France & $85 \%$ & $15 \%$ & $86 \%$ & $14 \%$ & $83 \%$ & $17 \%$ & $86 \%$ & $14 \%$ & $98 \%$ & $2 \%$ \\
\hline Campina & Netherlands & $98 \%$ & $2 \%$ & $95 \%$ & $5 \%$ & $100 \%$ & $0 \%$ & $100 \%$ & $0 \%$ & $100 \%$ & $0 \%$ \\
\hline Numico & Netherlands & $99 \%$ & $1 \%$ & $100 \%$ & $0 \%$ & $100 \%$ & $0 \%$ & $100 \%$ & $0 \%$ & $100 \%$ & $0 \%$ \\
\hline Barilla & Italy & $100 \%$ & $0 \%$ & $100 \%$ & $0 \%$ & $100 \%$ & $0 \%$ & $100 \%$ & $0 \%$ & $100 \%$ & $0 \%$ \\
\hline Bongrain & France & $100 \%$ & $0 \%$ & $95 \%$ & $5 \%$ & $100 \%$ & $0 \%$ & $100 \%$ & $0 \%$ & $100 \%$ & $0 \%$ \\
\hline
\end{tabular}

Notes: (1) Ranking based on EPO applications filed in 1978-2005. (2) Considered to be a Dutch company, following

AGRODATA and because its food research centre is in the Netherlands (Marsland 2003). (3) EU-15 for 1978-1994 and

EU-27 from 1995 onwards.

Source: Own elaboration based on AGRODATA, BvD AMADEUS, PATSTAT. 
Table 5. Type of innovation (Food v. Non-Food) * Location (Home v. Abroad) Crosstabulation (Subsample of EU-based F\&B MNEs, excluding Unilever)

\begin{tabular}{|c|c|c|c|c|}
\hline & $\chi^{\mathbf{2}}$ & Exact 2-sided & Cramer's V & $\mathbf{N}$ \\
\hline EPO patent applications filed 1978-2005 & $5.126(1)$ & 0.025 & $0.054(0.024)$ & 1,775 \\
\hline USPTO patents filed 1978-2001 & $0.950(1)$ & 0.356 & $0.035(0.330)$ & 757 \\
\hline Triadic families filed 1978-2000 & $0.977(1)$ & 0.331 & $0.050(0.323)$ & 384 \\
\hline International families filed 1978-2000 & $2.252(1)$ & 0.144 & $0.044(0.133)$ & 1,146 \\
\hline PCT families filed 1978-2000 & $1.042(1)$ & 0.324 & $0.044(0.307)$ & 536 \\
\hline
\end{tabular}

Ho: Food and non-food inventions are equally distributed between home and abroad; $\mathrm{N}=55$.

Table 6. Type of innovation (Food v. Non-Food)* Location (EU v. elsewhere)

Crosstabulation (Subsample of EU-based F\&B MNEs)

\begin{tabular}{|c|c|c|c|c|}
\hline & $\chi^{2}$ & Exact 2-sided & Cramer's V & $\mathbf{N}$ \\
\hline \multicolumn{5}{|c|}{ EPO Applications filed 1978-2005 } \\
\hline EU-15 (1978-1994) & $55.867(1)$ & 0.000 & $0.142(0.000)$ & 2,780 \\
\hline EU-27 (1995-2005) & $138.523(1)$ & 0.000 & $0.193(0.000)$ & 3,705 \\
\hline \multicolumn{5}{|l|}{ USPTO patents filed 1978-2001 } \\
\hline EU-15 (1978-1994) & $72.409(1)$ & 0.000 & $0.234(0.000)$ & 1,321 \\
\hline EU-27 (1995-2001) & $87.920(1)$ & 0.000 & $0.229(0.000)$ & 1,674 \\
\hline \multicolumn{5}{|c|}{ Triadic patent families filed $1978-2000$} \\
\hline EU-15 (1978-1994) & $38.765(1)$ & 0.000 & $0.179(0.000)$ & 1,211 \\
\hline EU-27 (1995-2000) & $1.251(1)$ & 0.305 & $0.048(0.263)$ & 543 \\
\hline \multicolumn{5}{|c|}{ International patent families filed 1978-2000 } \\
\hline EU-15 (1978-1994) & $59.081(1)$ & 0.000 & $0.145(0.000)$ & 2,828 \\
\hline EU-27 (1995-2000) & $23.673(1)$ & 0.000 & $0.117(0.000)$ & 1,731 \\
\hline \multicolumn{5}{|c|}{ PCT patent families filed 1978-2000 } \\
\hline EU-15 (1978-1994) & $13.618(1)$ & 0.000 & $0.140(0.000)$ & 695 \\
\hline EU-27 (1995-2000) & $4.732(1)$ & 0.031 & $0.060(0.030)$ & 1,308 \\
\hline
\end{tabular}

Ho: Food and non-food inventions are equally distributed between EU and elsewhere; $\mathrm{N}=56$. 